

\section{CONTENTS CONTD.}

\section{H.-J. FôrSTER:}

The chemical composition of uraninite in Variscan granites of the Erzgebirge, Germany

\section{G. Y. JEONG AND Y. H. KIM:}

Goldmanile from the black slates of the Ogcheon belt, Korea

\section{F. Primciyalle, A. Della Giusta, A. De Min} AND E. M. PicarLLL:

Crystal chemistry and significance of cation ordering in Mg-Al rich spinels from high-grade hornfels

(Predazzo-Monzoni, NE Italy)

\section{S. V. Krivolichey, G. L. Staroua ano S. K. Filatov:}

'Foce-10-face' relationships between oxocentred tetrahedro and calion-centred retrahedral oxyanions in crystal structures of minerals and inorganic compounds

M. RIEDER AND 14 MEMBERS of the IMA CNMMN Mica Subcommittee: Nomenclature of the micas

1997 Mineralogical Society — Schlumberger Award

1997 Mineralogical Society Max Hey Medal

Obituaries

Book Reviews

39
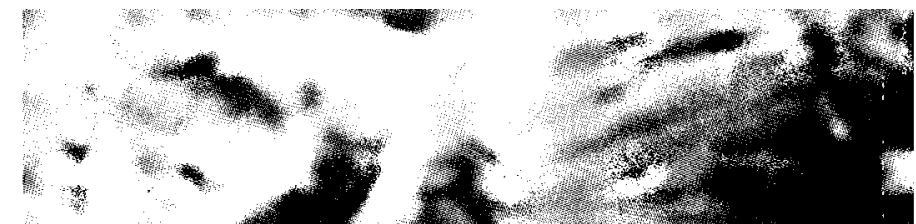